\title{
Porównanie wybranych typów słowotwórczych w zakresie rzeczownikowych formacji deminutywnych $z$ różnymi formantami w języku polskim i w języku bułgarskim
}

Słow a klucze: słowotwórstwo, polskie i bułgarskie deminutywa rzeczownikowe, formanty zdrabniające

Rzeczownikowe formacje deminutywne są najbardziej produktywną kategorią rzeczowników w polszczyźnie, bułgarszczyźnie, jak i w pozostałych językach słowiańskich. Uznaje się je za konstrukcje o charakterze potencjalnym, które stanowią zbiór otwarty, rozszerzany w wyniku zastosowania odpowiednich regu1 ${ }^{1}$. Deminutywa charakteryzują się dużą regularnością derywacji. W omawianych językach, jak i w pozostałych językach słowiańskich, powstają na drodze derywacji sufiksalnej dodatniej lub wymiennej.

Pod pojęciem rzeczownikowych formacji deminutywnych rozumiem zatem rzeczowniki odrzeczownikowe powstałe na drodze derywacji sufiksalnej dodatniej lub wymiennej. Utworzone za pomocą formantów deminutywnych derywaty rozumiane sa jako struktury sekundarne, istniejące w opozycji: wyraz podstawowy (neutralny pod względem znaczenia) $\leftrightarrow$ deminutywum (modyfikacja znaczenia - zmiana rozmiaru, subiektywna ocena mówiącego do przedmiotu).

Wśród deminutywów wyróżniam dwie grupy: deminutywa właściwe oraz deminutywa formalne. Do deminutywów właściwych zaliczam formacje utwo-

1 R. Grzegorczykowa (1974: 109-110). 
rzone od nazw przedmiotów, których główną cechą jest sygnalizowanie małości, np. pol. dom $\rightarrow$ domek, okno $\rightarrow$ okienko; bułg. къща $\rightarrow$ къщичка, прозорец $\rightarrow$ прозорче.

Deminutywa formalne tworzą kilka podgrup:

- zdrobnienia, w których między wyrazem podstawowym i pochodnym zostaje zachowane pewne ogólne podobieństwo znaczeń, np. podobieństwo kształtu, funkcji, surowca itp.: pol. mlyn $\rightarrow$ mlynek, dzwon $\rightarrow$ dzwonek, guma $\rightarrow$ gumka; bułg. мелница $\rightarrow$ мелничка, камбана $\rightarrow$ камбанка, гума $\rightarrow$ гумичка;

- zdrobnienia wnoszące znaczenie syngulatywności i partytywności, które nazywają bądź pojedynczy element pojęcia wskazanego w wyrazie podstawowym, bądź jego część, np.: pol. słoma $\rightarrow$ słomka, ogień $\rightarrow$ ognik, pyt $\rightarrow$ pyłek, ciasto $\rightarrow$ ciastko; bułg. слама $\rightarrow$ сламка, огън $\rightarrow$ огънче, nух $\rightarrow$ пухче, баница $\rightarrow$ баничка;

- zdrobnienia emfatyczne, które odnoszą się do:

a) pojęć stałych pod względem rozmiarów, np.: pol. dzień $\rightarrow$ dzionek, słońce $\rightarrow$ stonko; bułg. сльнце $\rightarrow$ сльнчице, зима $\rightarrow$ зимичка;

b) rzeczowników abstrakcyjnych, np.: pol. cnota $\rightarrow$ cnotka, idea $\rightarrow$ idej$k a$, ambicja $\rightarrow$ ambicyjka; bułg. амбиция $\rightarrow$ амбицийка, нужда $\rightarrow$ нуждииа, дарба $\rightarrow$ дарбииа;

c) nazw istot młodych, np.: pol. gęś $\rightarrow$ gęsię, prosię $\rightarrow$ prosiatko, szewc $\rightarrow$ szewczyk, krawiec $\rightarrow$ krawczyk; bułg. прасе $\rightarrow$ прасенце, моряк $\rightarrow$ моряче, чирак $\rightarrow$ чираче.

Inwentarz formantów deminutywnych w obu językach jest bardzo bogaty.

W języku polskim przedstawia się on następująco:

1) dla rzeczowników rodzaju męskiego:

- -ek (dom $\rightarrow$ domek) oraz warianty rozszerzone: -uszek (placek $\rightarrow$ placuszek), -aszek (kij $\rightarrow$ kijaszek), -iszek (brat $\rightarrow$ braciszek), -atek (kawatek $\rightarrow$ kawalatek);

- $-i k /-y k(b u t \rightarrow b u c i k)$ oraz warianty rozszerzone: -czyk (ślusarz $\rightarrow$ ślusar$c z y k)$

- $-a k$ (pies - psiak);

2) dla rzeczowników rodzaju żeńskiego:

- $-k a(k o k a r d a \rightarrow k o k a r d k a),-k a^{2}$ (jasła $\rightarrow$ jasetka) oraz warianty rozszerzone: -eczkal (uzda $\rightarrow$ uzdeczka), -eczka² (usta $\rightarrow$ usteczka), -yczka 
$($ twarz $\rightarrow$ twarzyczka), -utka (deska $\rightarrow$ deszczułka), -uszka $($ paczka $\rightarrow$ paczuszka), -etka (orgia $\rightarrow$ orgietka), -eńka (chwila $\rightarrow$ chwileńka);

3) dla rzeczowników rodzaju nijakiego:

- $\quad$-ko (błoto $\rightarrow$ błotko) oraz warianty rozszerzone: -eczko (miasto $\rightarrow$ miasteczko), -eńko (cudo $\rightarrow$ cudeńko), -etko (pole $\rightarrow$ poletko), -uszko (jabtko $\rightarrow$ jabłuszko), -onko (strzemię $\rightarrow$ strzemionko), -ączko (strzemię $\rightarrow$ strzemiqczko), -atko (piskle $\rightarrow$ pisklatko);

4) derywaty utworzone od rzeczowników reprezentujących kategorię plurale tantum:

- $-k i($ plecy $\rightarrow$ plecki), -iki/-yki (konszachty $\rightarrow$ konszachciki; kleszcze $\rightarrow$ kleszczyki),

- -iczki (drzwi $\rightarrow$ drzwiczki), -uszki (majtki $\rightarrow$ majtuszki).

W słowotwórstwie bułgarskim występują następujące formanty deminutywne:

1) dla rzeczowników rodzaju męskiego:

- $-е и(з ъ б \rightarrow з ъ б е и) ;$

2) dla rzeczowników rodzaju żeńskiego:

- -ка (буза $\rightarrow$ бузка), -ичка (баклава $\rightarrow$ баклавичка), -урка (къща $\rightarrow$ къмурка);

- -ица (глава $\rightarrow$ главица), -чица (сол $\rightarrow$ солчица);

3) dla rzeczowników rodzaju nijakiego:

- -це (агне $\rightarrow$ агънце), -ице (лице $\rightarrow$ личище), -енце (око $\rightarrow$ оченце);

4) dla rzeczowników rodzaju męskiego i żeńskiego:

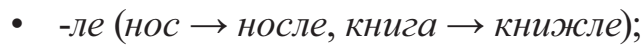

5) dla rzeczowników rodzaju męskiego, żeńskiego i nijakiego:

- -че (джоб $\rightarrow$ джобче, жаба $\rightarrow$ жабче, дърво $\rightarrow$ дръвче);

- -е (ключ $\rightarrow$ ключе, гъска $\rightarrow$ гъсе, палто $\rightarrow$ палте);

6) derywaty utworzone od rzeczowników w liczbie mnogiej oraz od rzeczowników reprezentujących kategorię plurale tantum:

- -ки (потури $\rightarrow$ потурки), -ички (гащи $\rightarrow$ гащиички);

- -иа (очила $\rightarrow$ очилиа), -ица (хора $\rightarrow$ хорииа), -енца (гащи $\rightarrow$ гащениа).

Celem niniejszego artykułu jest porównanie typów słowotwórczych w zakresie odpowiadających sobie polskich i bułgarskich rzeczownikowych formacji deminutywnych, utworzonych za pomocą różnych formantów w obu językach. Skonfrontowane zostaną:

a) formacje deminutywne na -ek $\mathrm{i}-i k \mathrm{w}$ języku polskim $\mathrm{z}$ formacjami na -чe, -e $\mathrm{i}-e u \mathrm{w}$ języku bułgarskim; 
b) polskie deminutywa $\mathrm{z}$ formantem -czyk $\mathrm{z}$ odpowiadającymi im formacjami w języku bułgarskim;

c) bułgarskie formacje deminutywne na -uщųa $\mathrm{z}$ tożsamymi znaczeniowo deminutywami w języku polskim;

d) formacje deminutywne na -ko w języku polskim z formacjami na -цe/-uцe w języku bułgarskim;

e) formacje deminutywne na -onko w języku polskim z formacjami na -енце w języku bułgarskim.

Zdrobnienia będące podstawą porównania pochodzą ze słowników, które wymieniam w załączonym wykazie źródeł ekscerpcji materiału.

\section{Porównanie polskich formacji deminutywnych na -ek $\mathrm{i}-i k \mathrm{z}$ formacja- mi na -чe, -e i -eц w języku bułgarskim}

Deminutywa od rzeczowników rodzaju męskiego tworzone są w języku polskim za pomocą dwóch formantów podstawowych -ek i -ik. W języku bułgarskim od podstaw będących rzeczownikami rodzaju męskiego derywują deminutywne formanty -чe, - $\mathrm{i}-e u$. Zatem polskim zdrobnieniom na -ek i -ik odpowiadają najczęściej bułgarskie formacje na -чe, -e lub -eu. Na gruncie języka bułgarskiego najliczniejszą grupę stanowią zdrobnienia z formantem -че. Na 739 derywatów bułgarskich, utworzonych od rzeczowników rodzaju męskiego za pomocą formantu -чe, 189 dotyczy wspólnego dla obu języków zasobu leksyki. Deminutywa te są derywatami od podstaw słowotwórczych identycznych w obu językach. Różnią się one formalnie: w języku polskim są to formancje na -ek lub $-i k$, natomiast w języku bułgarskim na -чe. Do tej grupy należą takie derywaty, jak np.: abażurek 'абажурче', autobusik 'автобусче', adwokacik 'адвокатче', aniołek 'ангелче', aparacik 'anapamче', balonik 'балонче', bilecik 'билетче', wagonik 'вагонче', gramik 'грамче', grosik 'грошче', gołabek 'гълъбче', diamеncik 'диамантче', zabek 'зъбче', kalendarzyk 'календарче', поżуk 'ножче', nитеrek 'номерче', filmik 'филмче', szalik 'шалче'.

Warto zauważyć, że istotną cechą różnicującą omawiane formacje w obu językach, poza występowaniem różnych formantów, jest zmiana rodzaju gramatycznego bułgarskich derywatów z formantami -че i -e w stosunku do podstaw słowotwórczych. Zgodność rodzaju gramatycznego między derywatem i wyrazem podstawowym jest regułą towarzyszącą tworzeniu rzeczowników zdrobniałych na $-e k \mathrm{i}-i k \mathrm{w}$ języku polskim. Natomiast w języku bułgarskim mamy w tym wypadku do czynienia z produktywną derywacją deminutywną, która 
powoduje zmianę rodzaju gramatycznego na nijaki w odniesieniu do wyrazu podstawowego, wykazującego rodzaj męski, np. ангел m. $\rightarrow$ ангелче n. Zmiana rodzaju gramatycznego zdrobnienia w stosunku do podstawy jest ważną cechą deminucji języka bułgarskiego, właściwą również językowi macedońskiemu ${ }^{2}$, i wyróżnia te języki na tle pozostałych języków słowiańskich.

W zgromadzonym materiale wystapiło 41 (na 222) formacji deminutywnych na -eu, które są w obu językach tożsame znaczeniowo. Pochodzą one od identycznych lub pokrewnych etymologicznie podstaw słowotwórczych, różnią się zaś formalnie. W języku polskim występują z formantem -ek lub -ik, natomiast w języku bułgarskim z formantem -eu. Są to takie derywaty, jak np.: bankiесіk 'банкетеи', bobek 'бобеи', brzеżek 'брежеи', wiaterek 'ветреи', głоsik 'гласеи', doтек 'домеи', deszczyk 'дъждеи', kominek 'коминеи', тrоzik 'мразеи', obłoczek 'облачеи', orzeszek 'орешеи', chlebek 'хлебеи', człowieczek 'човечеи'.

Z tożsamością znaczeniową derywatu i identycznością lub pokrewieństwem etymologicznym podstawy mamy do czynienia w 16 (na 144) formacjach deminutywnych, które $\mathrm{w}$ języku bułgarskim tworzone są za pomocą formantu -e: език $\rightarrow$ езиче 'је̨zyk $\rightarrow$ języczek', заек $\rightarrow$ зайче 'zając $\rightarrow$ zajaczek', замък $\rightarrow$ замъче 'zamek $\rightarrow$ zamесzek', ключ $\rightarrow$ ключе 'klucz $\rightarrow$ kluczyk', коняк $\rightarrow$ коняче 'koniak $\rightarrow$ koniaczek', котел $\rightarrow$ котле 'kociol $\rightarrow$ kociołek', кръщелник $\rightarrow$ кръщелниче 'chrześniak $\rightarrow$ chrześniaczek', лакомник $\rightarrow$ лакомниче 'takomczuch $\rightarrow$ takomczuszek', мозък $\rightarrow$ мозъче 'mózg $\rightarrow$ móżdżek', молитвеник $\rightarrow$ молитвениче 'modlitewnik $\rightarrow$ modlitewniczek', паметник $\rightarrow$ паметниче 'pamiętnik $\rightarrow$ pamiętniczek', паяк $\rightarrow$ паяче 'pajak $\rightarrow$ pajaczek', подарък $\rightarrow$ nодаръче 'podarunek $\rightarrow$ podaruneczek', поток $\rightarrow$ поточе 'potok $\rightarrow$ potoczek', чайник $\rightarrow$ чайниче 'czajnik $\rightarrow$ czajniczek', чердак $\rightarrow$ чердаче 'czerdak $\rightarrow$ czerdaczek'.

W języku bułgarskim poświadczona jest grupa derywatów utworzonych od rzeczowników rodzaju męskiego za pomocą formantu -чe, którym odpowiadają polskie deminutywa na $-k a$. Derywaty te tworzone są w obu językach od podstaw słowotwórczych pokrewnych etymologicznie, ale różniących się rodzajem gramatycznym.

W tej grupie formacji wyrazy motywujące w polszczyźnie mają rodzaj żeński, natomiast w języku bułgarskim są one rodzaju męskiego, np.: anegdota

2 O towarzyszącej deminucji zmianie rodzaju gramatycznego derywatu w stosunku do podstawy słowotwórczej w języku macedońskim pisał J. Sokołowski (2007: 212-219). 
$\rightarrow$ anegdotka 'анекдот $\rightarrow$ анекдотче', aspiryna $\rightarrow$ aspirynka 'acnирин $\rightarrow$ аспиринче', aureola $\rightarrow$ aureolka 'ореол $\rightarrow$ ореолеu', banderola $\rightarrow$ banderolka 'бандерол $\rightarrow$ бандеролче', wazelina $\rightarrow$ wazelinka 'вазелин $\rightarrow$ вазелинче', witamina $\rightarrow$ witaminka 'витамин $\rightarrow$ витаминче', glista $\rightarrow$ glizdeczka 'глист $\rightarrow$ глистче', grypa $\rightarrow$ grypka 'грип $\rightarrow$ грипче', etykieta $\rightarrow$ etykietka 'етикет $\rightarrow$ етикетче', makieta $\rightarrow$ makietka 'макет $\rightarrow$ макетче', szafa $\rightarrow$ szafka ' шкаф $\rightarrow$ шкафче'.

Odrębną grupę, wyróżniającą się spośród pozostałych deminutywów utworzonych od rzeczowników rodzaju męskiego w języku polskim, stanowią zdrobnienia powstałe na drodze wymiany sufiksoidu $-e n$ na $-y k$. Formacjom tym odpowiadają w języku bułgarskim deminutywa utworzone na drodze derywacji dodatniej sufiksalnej za pomocą formantu -e lub -чe, $\mathrm{tj}$. kamień $\rightarrow$ kamyk 'камък $\rightarrow$ камъче', krzemień $\rightarrow$ krzетуk 'кремък $\rightarrow$ кремъче', płomień $\rightarrow$ płomуk 'пламък $\rightarrow$ пламъче/пламъчеи', је̨сzтіеи́ $\rightarrow$ jęсzтуk 'ечемик $\rightarrow$ ечемиче/ ечемичеи', promień $\rightarrow$ promyk 'льч $\rightarrow$ льче', rzemień $\rightarrow$ rzemyk 'ремък $\rightarrow$ ремъче', grzebień $\rightarrow$ grzebyk 'гребен $\rightarrow$ гребенче', strumień $\rightarrow$ strumyk 'ручей $\rightarrow$ ручейче'. Jak widać z przytoczonego materiału, możliwe są w dwu wypadkach formacje zdrobniałe na -ец, tj. ечемичец і пламъчец.

Formant -yk o funkcji zdrabniającej obsługuje w języku polskim rzeczowniki o dawnych tematach rozszerzonych o-en- (ps. *ęčmy, ęčsmene; *kamy, kamene; *remy, remene; *plamy, plamene), które we współczesnej polszczyźnie występują w postaci z sufiksoidem -eń, pochodzącym z dawnego biernika 1. poj. Derywaty deminutywne powstawały przez dodanie formantu zdrabniającego do postaci rzeczownika zakończonego w mianowniku na -y. We wszystkich wymienionych wyżej polskich parach słowotwórczych można wskazać opozycję formalną między sufiksoidem -'eń a formantem -yk. Nieco inaczej wygląda struktura słowotwórcza rzeczownika grzebień, dla którego diachronicznie wyrazem motywującym jest czasownik grzebać. Chociaż w parach słowotwórczych typu kamień $\rightarrow$ kamyk mamy do czynienia z opozycja skojarzonq, wtórna, niederywacyjna $^{3}$, to z synchronicznego punktu widzenia można w tym wypadku widzieć przykład na derywację wymienną. Obok tej grupy rzeczowników wyodrębnia się we współczesnym języku polskim ponad 40 rzeczowników rodzaju męskiego na -eń, od których tworzy się deminutywa za pomocą formantu -ek, np. dzień $\rightarrow$ dzionek, ogień $\rightarrow$ ogieniek, pierścień $\rightarrow$ pierścionek, korzeń $\rightarrow$ korzonek, jeleń $\rightarrow$ jelonek.

3 Pojęcie opozycji skojarzonej stosuję za B. Kreją (1989: 11). 
Warto zwrócić uwagę na fakt, że rzeczowniki reprezentujące dawne tematy spółgłoskowe na -en- występują we współczesnym języku bułgarskim w postaci z pierwotnym formantem zdrabniającm $-k$. Słowniki języka bułgarskiego rejestrują również formację камен obok камък, ale jest ona opatrzona kwalifikatorem 'przestarzałe'.

\section{Porównanie polskich deminutywów $\mathrm{z}$ formantem -czyk $\mathrm{z}$ odpowiadają- cymi im formacjami deminutywnymi w języku bułgarskim}

Zdrobnienia na -czyk, oznaczające młodych, niedoświadczonych wykonawców zawodu lub pomocników w zawodzie, należą w polszczyźnie do nieproduktywnych typów słowotwórczych i dotyczą zamkniętej grupy derywatów uznawanych za przestarzałe, pochodzących od podstaw słowotwórczych na arz (wyjątki: fryzjer $\rightarrow$ fryzjerczyk, lokaj $\rightarrow$ lokajczyk): aptekarz $\rightarrow$ aptekarczyk, bankier $\rightarrow$ bankierczyk, bednarz $\rightarrow$ bednarczyk, drukarz $\rightarrow$ drukarczyk, kamieniarz $\rightarrow$ kamieniarczyk, kominiarz $\rightarrow$ kominiarczyk, kotlarz $\rightarrow$ kotlarczyk, księgarz $\rightarrow$ księgarczyk, kucharz $\rightarrow$ kucharczyk, kuśnierz $\rightarrow$ kuśnierczyk, lekarz $\rightarrow$ lekarczyk, malarz $\rightarrow$ malarczyk, mlynarz $\rightarrow$ mlynarczyk, mularz $\rightarrow$ mularczyk, piekarz $\rightarrow$ piekarczyk, pisarz $\rightarrow$ pisarczyk, piwowar $\rightarrow$ piwowar$c z y k$, psiarz $\rightarrow$ psiarczyk, ślusarz $\rightarrow$ ślusarczyk. Formacjom tym w języku bułgarskim odpowiadają deminutywa $\mathrm{z}$ formantem -че. Zasadnicza jednak różnica między systemami słowotwórczymi porównywanych języków polega na tym, że formant -чe cechuje znaczna produktywność. Bez trudu znajdujemy deminutywa bułgarskie tożsame znaczeniowo w stosunku do większości polskich formacji na -czyk, np. fryzjer $\rightarrow$ fryzjerczyk 'фрризьор $\rightarrow$ фризьиорче', apte$k a r z \rightarrow$ aptekarczyk 'аптекар $\rightarrow$ аптекарче', bednarz $\rightarrow$ bednarczyk 'бъчвар $\rightarrow$ бъчварче', drukarz $\rightarrow$ drukarczyk 'nечатар $\rightarrow$ nечатарче', kamieniarz $\rightarrow$ kaтiепiarczyk 'каменар $\rightarrow$ каменарче', kotlarz $\rightarrow$ kotlarczyk 'котлар $\rightarrow$ котларче/бакърджия $\rightarrow$ бакърджийче/казанджия $\rightarrow$ казанджийче', księgarz $\rightarrow$ księgarczyk 'книжар $\rightarrow$ книжарче', kuśnierz $\rightarrow$ kuśnierczyk 'кожухар $\rightarrow$ кожухарче', lekarz $\rightarrow$ lekarczyk 'лекар $\rightarrow$ лекарче', malarz $\rightarrow$ malarczyk 'бояджия $\rightarrow$ бояджийче', mtynarz $\rightarrow$ mtynarczyk 'воденичар $\rightarrow$ воденичарче', piekarz $\rightarrow$ piekarczyk 'хлебар $\rightarrow$ хлебарче / фурнаджия $\rightarrow$ фурнаджийче', pisarz $\rightarrow$ pisarczyk 'писател $\rightarrow$ писателче', ślusarz $\rightarrow$ ślusarczyk 'шлосер $\rightarrow$ шлосерче'.

W języku bułgarskim derywaty tego typu są licznie poświadczone. Formant -че derywuje deminutywa o znaczeniu młodych wykonawców zawodu nie tyl- 
ko od rzeczowników oznaczających nazwy zawodów zakończone na -ap (formant odpowiadający polskiemu przyrostkowi -arz), np. архивар $\rightarrow$ архиварче, биволар $\rightarrow$ биволарче, зидар $\rightarrow$ зидарче, златар $\rightarrow$ златарче, коняр $\rightarrow$ конярче, ale także od rzeczowników z tej kategorii słowotwórczej zakończonych na inne sufiksy, tj. od rzeczowników na -ьop, nр. актьор $\rightarrow$ актьорче, боксьор $\rightarrow$ боксьорче, миньор $\rightarrow$ миньорче; па -джия, пр. гемиджия $\rightarrow$ гемиджийче, бояджия $\rightarrow$ бояджийче, казанджия $\rightarrow$ казанджийче, калайджия $\rightarrow$ калайджийче; na -чия, nр. геврекчия $\rightarrow$ геврекчийче, джебчия $\rightarrow$ джебчийче. Tym formacjom będą odpowiadały polskie zdrobnienia na -ek i -ik. Formacje na -че cechuje dodatnie lub ujemne zabarwienie emocjonalne. W odróżnieniu od polskich formacji na -czyk, wskazujących na nazwy młodych, niedoświadczonych wykonawców zawodów lub pomocników w zawodzie, derywaty bułgarskie mogą wyrażać ironię, lekceważenie, pobłażliwość.

Warto zwrócić też uwagę na deminutywa tworzone w obu językach od nazw wykonawców czynności i zawodów. W języku polskim występuje nieliczna grupa derywatów zdrobniałych na -ek lub -ik, które mogą wskazywać na młody wiek osoby, ale mają one zwykle odcień ironii, lekceważenia. W zgromadzonym materiale odnotowałam następujące przykłady, którym odpowiadają tożsame znaczeniowo formacje na -че w języku bułgarskim: doktor $\rightarrow$ doktorek 'doктор $\rightarrow$ докторче', inżynier $\rightarrow$ inżynierek 'инженер $\rightarrow$ инженерче', konduktor $\rightarrow$ konduktorek 'кондуктор $\rightarrow$ кондукторче', majster $\rightarrow$ majsterek 'майстор $\rightarrow$ майсторче', oficer $\rightarrow$ oficerek 'офииер $\rightarrow$ офииерче', rzemieślnik $\rightarrow$ rzemieślniczek 'занаятчия $\rightarrow$ занаятчийче', muzykant $\rightarrow$ muzykancik 'музукант $\rightarrow$ музикантче'.

Nazwy zawodów oraz wykonawców czynności tworzy się w języku bułgarskim od wszystkich formacji na -джия oraz -чия (a są to szczególnie produktywne typy słowotwórcze - słownik a tergo języka bułgarskiego rejestruje 158 formacji na -джия i 64 na -чия ) za pomocą formantu -че.

Oprócz tego w obu językach deminutywizacji podlegają zapożyczone nazwy osobowe na -ant $\mathrm{i}$-ent. Na gruncie polszczyzny są one obsługiwane przez formant deminutywny -ik, zaś w języku bułgarskim przez formant -чe, np. adiutant $\rightarrow$ adiutancik 'aдютант $\rightarrow$ адютантче', emigrant $\rightarrow$ emigrancik 'емигрант $\rightarrow$ емигрантче', fabrykant $\rightarrow$ fabrykancik 'фабрикант $\rightarrow$ фабрикантче', intrygant $\rightarrow$ intrygancik 'интригант $\rightarrow$ интригантче', komediant $\rightarrow$ komediancik 'комедиант $\rightarrow$ комедиантче', pedant $\rightarrow$ pedancik 'педант $\rightarrow$ педантче', sierżant $\rightarrow$ sierżancik 'сержант $\rightarrow$ сержантче', inteligent $\rightarrow$ in- 
teligencik 'интелигент $\rightarrow$ интелигентче', student $\rightarrow$ studencik 'студент $\rightarrow$ студентче'.

Interesująca jest również w języku bułgarskim możliwość regularnego tworzenia formacji zdrobniałych na -чe od nazw osobowych na -ucm (pol. -ista), które nie ulegają deminutywizacji w języku polskim, np. анархист $\rightarrow$ анархистче 'pol. anarchista', егоист $\rightarrow$ егоистче 'pol. egoista', капиталист $\rightarrow$ капиталистче 'pol. kapitalista', комунист $\rightarrow$ комунистче 'pol. komunista', гимназист $\rightarrow$ гимназистче 'pol. gimnazjalista'.

\section{Porównanie bułgarskich formacji deminutywnych na -чицุa $\mathrm{z}$ tożsa- mymi znaczeniowo deminutywami w języku polskim}

W języku bułgarskim istnieje nieliczna grupa rzeczowników rodzaju żeńskiego jedno- lub dwusylabowych zakończonych spółgłoską lub zbitką spółgłosek, od których tworzone są zdrobnienia za pomocą formatu -чuua. Dla pewnej grupy tego typu zdrobnień bułgarskich można wskazać tożsame znaczeniowo derywaty polskie, np. песен $\rightarrow$ песенчица 'piosenka $\rightarrow$ pioseneczka', вар $\rightarrow$ варчица 'wapno $\rightarrow$ wapienko', жар $\rightarrow$ жарчица 'żar $\rightarrow$ żarek', кал $\rightarrow$ калчица 'błoto $\rightarrow$ blotko', лой $\rightarrow$ лойчица 'lój $\rightarrow$ tojek', повест $\rightarrow$ nовестчица 'powieść $\rightarrow$ powiastka'. W tej grupie zdrobnień znajdują się również przykłady, których odpowiedniki będą należały do wyrazów rzadkich, kuriozalnych, np. кpъв $\rightarrow$ кръвчица 'krew $\rightarrow$ krewka', болест $\rightarrow$ болестчица 'choroba $\rightarrow$ choróbka', власт $\rightarrow$ властчица 'władza $\rightarrow$ władzka', завист $\rightarrow$ завистчица 'zawiść $\rightarrow$ zawistka', невеста $\rightarrow$ невестчица 'niewiasta $\rightarrow$ niewiastka'.

W języku bułgarskim za pomocą formantu -чuщa tworzone są deminutywa od podstaw słowotwórczych, których odpowiedniki polskie nie podlegają zdrabnianiu. Są to wyrazy: sól 'сол $\rightarrow$ солчица', cukier 'захар $\rightarrow$ захарчица', pomoc 'nомощ $\rightarrow$ помощччица'. Dotyczy to zatem deminutywów formalnych, które nie mają tożsamych znaczeniowo odpowiedników w języku polskim.

Warto zwrócić uwagę na formację любовчица zarejestrowaną w słownikach, której odpowiada znaczeniowo polski derywat miłostka. W tym miejscu należy zaznaczyć, że bułgarskie rzeczowniki oznaczające pojęcia i cechy abstrakcyjne na -ocm, w odróżnieniu od polskich rzeczowników na -ość, nie podlegają deminutywizacji. W języku polskim zdrobnienia od tej grupy rzeczowników abstrakcyjnych tworzone są za pomocą formantu - $k a$, który wnosi znaczenie syngulatywne, np. słabość $\rightarrow$ słabostka, śmiałość $\rightarrow$ śmiałostka, ciekawość $\rightarrow$ ciekawostka itd. Bułgarski system słowotwórczy nie wyklucza tego 
typu zdrobnień. Niektóre rzeczowniki bułgarskie na -ocm tworzą potencjalnie deminutywa za pomocą formantu -чица, np. лудост $\rightarrow$ лудостчица, слабост $\rightarrow$ слабостчица, смелост $\rightarrow$ смелостчица, грубост $\rightarrow$ грубостчица itd. W słownikach języka bułgarskiego brakuje jednak poświadczeń tego typu deminutywów, a przez nosicieli języka postrzegane są one jako możliwe, ale dziwaczne, rzadkie, kuriozalne. Często traktowane są jako neologizmy.

\section{Porównanie formacji deminutywnych na $-k o$ w języku polskim $\mathrm{z}$ for- macjami na -це/-ице w języku bułgarskim}

Dużą regularność i wyraźne podobieństwo wykazują formacje deminutywne na -ko w języku polskim i na -ụe w języku bułgarskim, tworzone od rzeczowników rodzaju nijakiego zakończonych w obu językach na -o lub -e. Zarówno w polszczyźnie, jak i w bułgarszczyźnie deminutywa te powstają na drodze derywacji dodatniej sufiksalnej i w obu językach zachowują rodzaj gramatyczny zgodny z rodzajem gramatycznym podstawy słowotwórczej, np. błoto $\rightarrow$ błotkо 'блато $\rightarrow$ блатие', wino $\rightarrow$ winko 'вино $\rightarrow$ винце', wrzeciono $\rightarrow$ wrzecion$k o$ 'вретено $\rightarrow$ вретенце', gniazdo $\rightarrow$ gniazdko 'гнездо $\rightarrow$ гнездие', dzieło $\rightarrow$ dzietko 'дело $\rightarrow$ делие', dluto $\rightarrow$ dlutko 'длето $\rightarrow$ длетие', żyto $\rightarrow$ żytko 'жито $\rightarrow$ житие', jezioro $\rightarrow$ jeziorko 'езеро $\rightarrow$ езерие', koryto $\rightarrow$ korytko, 'корито $\rightarrow$ коритие', mięso $\rightarrow$ mięsko 'месо $\rightarrow$ месие', pióro $\rightarrow$ piórko 'nеро $\rightarrow$ nepue'.

Deminutywa na -ko i -u̧e od rzeczowników rodzaju nijakiego w obu językach wykazuja podobieństwo ze względu na budowę słowotwórczą. Ponadto można stwierdzić również tożsamość funkcji znaczeniowych, jakie pełnią oba formanty zdrabniające w porównywanych językach. I tak formanty te mogą tworzyć zarówno deminutywa właściwe, np.: koryto $\rightarrow$ korytko 'кopumo $\rightarrow$ коритце', wiadro $\rightarrow$ wiaderko 'ведро $\rightarrow$ ведърие', wiosto $\rightarrow$ wiosetko 'гребло $\rightarrow$ гребълие', lustro $\rightarrow$ lusterko 'огледало $\rightarrow$ огледалие', tóżko $\rightarrow$ tóżeczko 'легло $\rightarrow$ легълие', wahadło $\rightarrow$ wahadełko 'махало $\rightarrow$ махалие', jak i deminutywa formalne, a wśród nich zdrobnienia o znaczeniu syngulatywności lub partytywności, nр.: злато $\rightarrow$ златие 'złoto $\rightarrow$ złotko', зърно $\rightarrow$ зрънце 'ziarno $\rightarrow$ ziarenko', szkło $\rightarrow$ szkiełko 'стъкло $\rightarrow$ стькълце', jak również zdrobnienia emfatyczne, powstałe od rzeczowników, których rozmiar jest trudny do określenia, np.: błoto $\rightarrow$ błotko 'блато $\rightarrow$ блатие', wino $\rightarrow$ winko 'вино $\rightarrow$ винще', mięso $\rightarrow$ mięsko 'месо $\rightarrow$ месие', mleko $\rightarrow$ mleczko 'мляко $\rightarrow$ млекце', zebranie $\rightarrow$ zebranko 'заседание $\rightarrow$ заседанийце'. W obu językach w rzeczownikach bę- 
dących zdrobnieniami od nazw części ciała omawiane formanty deminutywne mogą wskazywać zarówno na cechę małości fizycznej, jak i na wzmocnienie ładunku emocjonalnego, np. biodro $\rightarrow$ bioderko 'бедро $\rightarrow$ бедърие', gardto $\rightarrow$ gardetko 'гърло $\rightarrow$ гърлце', kolano $\rightarrow$ kolanko 'коляно $\rightarrow$ коленце', skrzydto $\rightarrow$ skrzydetko 'крило $\rightarrow$ крилче'.

W języku bułgarskim kilka rzeczowników rodzaju nijakiego tworzy deminutywa za pomocą formantu rozszerzonego -uue. Tym formacjom również odpowiadają polskie zdrobnienia na -ko: гнездо $\rightarrow$ гнездице 'gniazdo $\rightarrow$ gniazdko', грозде $\rightarrow$ гроздиие 'winogrono $\rightarrow$ winogronko', здраве $\rightarrow$ здравице 'zdrowie $\rightarrow$ zdrówko', лице $\rightarrow$ личиче 'lico $\rightarrow$ liczko', око $\rightarrow$ очице 'oko $\rightarrow$ oczko', сльнце $\rightarrow$ сльнчице 'słońce $\rightarrow$ słoneczko', яйще $\rightarrow$ яйчице 'jajko $\rightarrow$ jajeczko'. Wyjątek stanowi deminutywum od rzeczownika serce, które w języku polskim tworzone jest wyłącznie za pomocą formantu rozszerzonego -uszko (serce $\rightarrow$ serduszko), natomiast w języku bułgarskim występuje z formantem -uще (сърие $\rightarrow$ сърчище).

\section{Porównanie formacji deminutywnych na -onko w języku polskim $\mathrm{z}$ formacjami na -енце $\mathrm{w}$ języku bulgarskim}

Nielicznej grupie derywatów zdrobniałych z formantem -onko w języku polskim odpowiadają formacje na -енще w języku bułgarskim. W obu językach formacje te są derywowane od identycznych podstaw słowotwórczych, którymi sa rzeczowniki rodzaju nijakiego na pol. -ę/ bułg. -e, należące do dawnej deklinacji tematów spółgłoskowych z rozszerzeniem -en-. Odpowiedniości te są bardzo dokładne:

brzemię $\rightarrow$ brzemionko 'бреме $\rightarrow$ бременце', ciemię $\rightarrow$ ciemionko 'теме $\rightarrow$ темение', imię $\rightarrow$ imionko 'име $\rightarrow$ именце', ramię $\rightarrow$ ramionko 'paмо $\rightarrow$ раменце', strzemię $\rightarrow$ strzemionko 'стреме $\rightarrow$ стременце', wymię $\rightarrow$ wymion$k$ о 'виме $\rightarrow$ вименце', znamie $\rightarrow$ znamionko 'знаме $\rightarrow$ знаменце'.

W języku polskim formant -onko obsługuje wyłącznie wskazane powyżej formacje deminutywne. Jest to formant nieproduktywny. Natomiast w języku bułgarskim produktywność wyabstrahowanego wtórnie $\mathrm{z}$ tego typu formacji przyrostka -енце uległa znacznemu rozszerzeniu. Derywuje on deminutywa od licznych rzeczowników rodzaju nijakiego, np.: антре $\rightarrow$ антренце, въже $\rightarrow$ въженце, деколте $\rightarrow$ деколтенце, каре $\rightarrow$ каренце, кафе $\rightarrow$ кафенце, мезе $\rightarrow$ мезенце, палто $\rightarrow$ палтенце, тире $\rightarrow$ тиренще. Może służyć także do wprowadzania formacji deminutywnych drugiego stopnia od zdrobnień 
na -e, -ле oraz -че, пр.: гърло $\rightarrow$ гърле $\rightarrow$ гърленцуе, нос $\rightarrow$ носле $\rightarrow$ носленце, жаба $\rightarrow$ жабче $\rightarrow$ жабченце. Warto zauważyć, że formant -енцее tworzy zarówno deminutywa właściwe, jak i formalne. W języku bułgarskim derywuje przede wszystkim od rzeczowników dwusylabowych (deminutywa pierwszego stopnia). Istnieją zatem pewne ograniczenia formalne w dystrybucji tego przyrostka. Poza tym zdecydowana większość derywatów tego typu nie może tworzyć deminutywów za pomocą innych formantów obsługujących rzeczowniki rodzaju nijakiego.

W niniejszym artykule koncentruję się na odpowiadających sobie znaczeniowo formacjach deminutywnych, różniących się w obu językach ze względu na formant. Z przedstawionej analizy wynika, że istnieją zarówno podobieństwa, jak i różnice między porównywanymi językami w zakresie inwentarza deminutywnych formantów słowotwórczych, ich dystrybucji i produktywności, a także w zakresie relacji semantycznych między podstawami i derywatami. I tak polskim deminutywom na -ek i -ik odpowiadają najczęściej bułgarskie deminutywa z formantami -е, -че oraz -ле. Polskie zdrobnienia na -czyk znajdują swoje odpowiedniki bułgarskie $\mathrm{w}$ formacjach na -чe, $\mathrm{z}$ ta jednak różnica, że ten typ słowotwórczy w języku bułgarskim, w odróżnieniu od polszczyzny, charakteryzuje duża produktywność. Na gruncie języka bułgarskiego wyróżniają się formacje deminutywne na -чuц̧a, dla których wskazanie polskich odpowiedników przysparza wiele trudności, a niekiedy okazuje się wręcz niemożliwe. Duże podobieństwo wykazują rzeczowniki zdrobniałe na -ko w języku polskim i na -ųe w języku bułgarskim, tworzone w obu językach od rzeczowników rodzaju nijakiego zakończonych na -o lub -e. Polskim formacjom na -onko odpowiadają bułgarskie deminutywa na -енц̧е. We współczesnym języku polskim formacje tego typu obejmują zaledwie kilka przykładów, a dystrybucja sufiksu -onko ma ograniczony zasięg. Natomiast produktywność wyabstrahowanego z formacji typu ‘бременцее’ bułgarskiego sufiksu -енцее uległa znacznemu rozszerzeniu.

\section{Źródła materiału}

Андрейчин Л. (ред.), 1975, Обратен речник на съвременния български език, София: Издателство на БАН.

Чолакова К. (ред.), 1977-, Речник на българския език БАН, т. 1-12, София: Издателство на БАН.

Grzegorczy Kowa R. (red.), 1973, Indeks a tergo do Słownika języka polskiego pod red. W. Doroszewskiego, J. Puzynina, Warszawa: PWN. 
JADACKA H. (red.), 2001, Stownik gniazd slowotwórczych wspótczesnego języka ogólnopolskiego. Gniazda odrzeczownikowe, t. 2, Kraków: TAiWPN Universitas.

Пенчев Й. (ред.), 1999, Словообразувателен речник на съвременния български език, София: Академично издателство „Проф. Марин Дринов”.

Попов Д. (ред.), 1999, Български тълковен речник, София: Наука и Изкуство.

SzymczaK M. (red.), 1999, Stownik jezzyka polskiego, t. 1-3, Warszawa: PWN.

\section{Bibliografia}

БояДжиЕв Т., КуцАРОв И., Пенчев Й., 1998, Съвременен български език, София: Издателска къща „Петър Берон”.

Димитрова М., 1959, Умалителните имена в книжовния български език, Известия на Института за български език при БАН, кн. 6, с. 263-319.

ЕнчеВА Н., 1988, Към морфологичната характеристика на българските умалителни съществителни, Език и литература, кн. 6, с. 12-17.

Grzegorczykowa R., Puzynina J., 1979, Słowotwórstwo wspótczesnego języka polskiego. Rzeczowniki sufiksalne rodzime, Warszawa: PWN.

Grzegorczyoowa R., 1974, Zarys stowotwórstwa polskiego. Stowotwórstwo opisowe, Warszawa: PWN.

Heltberg K., O deminutywach i augmentatywach, 1964, Prace Filologiczne 18 (2), Warszawa, s. 93-102.

Иванчев С., 1987, Един особен начин за образуване на умалителни имена в българския език, [в:] За българския и класичните езиии, София.

Klimaszewska Z., 1983, Diminutive und augmentative Ausdrucksmöglichkeiten des Niederländischen, Deutschen und Polnischen, Wrocław: PAN, Komitet Neofilologiczny, Zakład Narodowy im. Ossolińskich.

KREJA B., 1969, Slowotwórstwo rzeczowników ekspresywnych w języku polskim. Formacje na: -ik, -isko, -ina, Gdańsk: GTN.

Kreja B., 1989, Z morfonologii i morfotaktyki wspótczesnej polszczyzny, Wrocław: Komitet Językoznawstwa PAN, Prace Językoznawcze 113.

Кръстев Б., 1976, Умалителността в българския език, София: Държавно издателство „Народна просвета”.

Мурдаров В., 1983, Съвременни словообразувателни проиеси. Очерк върху българското словообразуване, София: Наука и изкуство.

Мюлер-Отт Д., 1998, Продуктивността на умалителните суфикси с елемент -ки -и- в руския и българския език, Език и литература, кн. 3, с. 33-42.

НАумова В., 1905, Умалителните и увеличителни суфикси в новобългарския език, Известия на семинара по славянска филология, София, с. 217-250. 
PolańsKi K. (red.), Encyklopedia językoznawstwa ogólnego, Wrocław 1999: Zakład Narodowy im. Ossolińskich.

РАдевА В., 1987, Българското словообразуване, София: Университетско издателство „Св. Климент Охридски”.

РАдевА В., 1991, Словообразуването в българския книжовен език, София: Университетско издателство „Св. Климент Охридски”.

SiatkowsKa E., 1967, Deminutywa rzeczowników we współczesnych literackich językach zachodniosłowiańskich, Studia z filologii polskiej i słowiańskiej 6, s. 157-170.

SokoŁowski J., 2007, Mechanizmy deminucji i hipokryzacji w języku macedońskim i polskim na tle innych języków słowiańskich, w: Z polskich studiów slawistycznych, seria 11, Językoznawstwo, s. 212-219.

СПасова А., 1952, Словообразувателна функция на суфикс-ец в днешния книжовен български език, Български език кн. 3/4, с. 261-267.

Тилков Д., Стоянов С., Попов К. (red.), Граматика на съвременния български книжовен език, София 1993: Издателство на БАН.

WARCHOŁ S., 1984, Geneza i rozwój stowiańskich formacji ekspresywnych z sufiksalnym $-k-i-c-$, Warszawa: PWN.

\section{Ein Vergleich ausgewählter Wortbildungstypen im Bereich substantivischer Diminutivbildungen mit verschiedenen Suffixen im Polnischen und Bulgarischen}

\section{( Zus a m m e n f a s s u n g)}

Im vorliegenden Beitrag vergleiche ich ausgewählte Wortbildungstypen im Bereich äquivalenter polnischer und bulgarischer substantivischer Diminutive, die durch verschiedene Suffixe in beiden Sprachen gebildet werden. Es werden Folgendes konfrontiert:

a) die Diminutivsuffixe - $e k$ und -ik in der polnischen Sprache mit den Suffixen na -чe, - e und - eu in der bulgarischen Sprache;

b) die polnischen Diminutiva mit dem Suffix - czyk mit entsprechenden Suffixverwendungen im Bulgarischen;

c) die bulgarischen diminutiven Formen mit -чuц̧a mit bedeutungsäquivalenten Diminutiva im Polnischen;

d) die diminutiven Formen mit -ko im Polnischen mit den Formen mit -ụe/-uue im Bulgarischen;

e) die diminutiven Formen auf -onko im Polnischen mit Formen auf -енце im Bulgarischen. 